\title{
SACKING OF DEMOCRATIC GOVERNMENTS IN PAKISTAN: A CRITICAL REVIEW
}

\author{
Summer Sultana* \\ Nuzhat Jahan**
}

\begin{abstract}
A commonly accepted definition of the democracy is; "Rule of the majority by the supreme power vested in the people and exercised by them directly". The democratic government may remain in power until and unless people repose the confidence over it. In Pakistan the main reason of failure of the democracy is that, it is generally against the social behavior of Pakistan. Just because of this the democracy could not come around in Pakistan, yet people cannot be incriminated for the same. The history is witnessed that Pakistani people had supported all social movements having collective ambitions but unluckily after freedom no political party or leadership was available to Pakistanis which could do something for them. Soon after freedom bureaucrats had prevalence in the government due to this the overall control remained in the hands of Governor General or non-representatives. So, democratic institutions could not attain freedom from them. Undoubtedly from the beginning the Pakistan Army attained a dominating role in the system of government and in the field of politics and during the last 60 years they remained in rule for more than a half of the tenure and the political governments were never allowed to take any step freely. In the current scenario Pakistan should have to pass through a democratic way which was stopped by the Armed forces and bureaucracy by adopting different means.
\end{abstract}

Keywords: Pakistan, freedom, democracy, military, bureaucrats, dominating role

\section{Introduction}

The matter concerning lack of democracy and sacking of democratic governments in Pakistan remained different from various other countries especially the Asian countries. The address of the Quid-e-Azam Muhammad Ali Jinnah after independence presents an image of democratic and secular Pakistan. It was a despicable theory for the feudatory for this new country, who was the part of the first constituent assembly. This assembly was broken by the bureaucrat Governor General Ghulam Muhammad in 1953. Consequently against this decision a suit was filed... in Tameez-ud-Din Khan court. The verdict of the then Chief Justice in favour of this decision caused great loss to the democracy. Due to this decision no constitution could be firmed in 60 years after the independence. In this period several of governments and ministries were changed. Since soon after the freedom series of wars and disputes started between Pakistan and India hence, defense of the country became the first priority for the forces. Therefore, pacts like "SETO" and "CENTO" were arranged with America and the Pakistan Army attained an extraordinary

\footnotetext{
* Summer Sultana, Ph.D. Associate Professor, Department of Political Science, University of Karachi

${ }^{* *}$ Nuzhat Jahan, Research Scholar, Department of Political Science, University of Karachi
} 
position in the world politics, due to which an army general became Defense Minister and with this uniform entered in our national politics and it persisted to the extent that Marshall Law was encroached in 1958.

From 1947 to 1958, experience of unelected parliament was done. Though during this period elections for Provincial Assemblies were helded, but elections for National Assembly never held. Two constituent assemblies acted as legislation institution and the discretions were being transferred between the Governor General (President) and Prime Minister. Then in 1958 this political system was entirely changed. ${ }^{1}$

Avenue opened for treachery from constitution and to make hurdles in the democratic process. Although articles 243 and 245 of the constitution place the army under the direct control of Federal Government and ordered is given to help the civil government. The constitution of 1956 was acceptable to both the provinces. If elections, which was the only solution of the political unrest, were arranged under it, the tragedy of 1970 might not occurred, that was direct reaction of disappointment from democracy.

There may be dissimilarity whether Sikandar Mirza make up the mind of Ayub Khan to impose Marshall Law or Ayub Khan planned to use Sikandar Mirza. Whatever would be the reality, assemblies and constitution were annulled. The both were equally responsible for committing the said offence. Sikandar Mirza was set aside due to the misconception that he had mutual help of the forces, whereas the army was under the control of Ayub Khan who handled the power as he could not bear partnership of ones in the power. ${ }^{2}$

In 1970 first time general elections on adult franchise bases were held in Pakistan in that the people had taken part with... but General A. M. Yahya Khan and Zulfiqar Ali Bhutto had not handed over power to Sheikh Mujeeb-ur-Rehman, and just to be safe their own interests both of the politicians divided the country into two pieces. Zulfiqar Ali Bhutto was in favor of two Prime Ministers in the country, whilst he had only gain seats in two provinces from four Provinces of West Pakistan. But he had decided not to hand over the power to Sheikh Mujeeb-ur-Rehman which was fulfilled by the prevailing circumstances.

The painful side of the first national elections was that, these were neither got conducted under accepted and leading lawful principles nor any conciliation observed among the political parties taking part in the elections. It should be noted that these elections were got conducted under the order of a army and political group after removal of 1962 constitution and their aim was to ratify Ayub Khan's desire to conclude the political system instead of forming a new one. ${ }^{3}$

After 1971 the elections of 1977 were held in Bhutto's period. Results of which were hard to be accept by the people and political parties due to unfair means adopted by Bhutto and Public agitation started against Peoples Party. Zulfiqar Ali Bhutto maintained

\footnotetext{
${ }^{1}$ Selg S. Harrison, Paul H Kreisberg and Dinnis Kux. India and Pakistan, (USA: Woodrow Wilson Center Press and Cambridge University, Press, 1999)

${ }^{2}$ Rafique Dogar. Civil and Military Conspiracies, (Lahore: Deed Shaneed Publisher , 1996), p.52

${ }^{3}$ Lawrence Ziring. Pakistan in the Twentieth Century, (Karachi: Oxford University Press, 1997), p.212
} 
his own stubbornness and invited Marshall Law only for not controlling of fresh elections. General Zia-ul-Haq had suspended the constitution and promised to hold election in 90 days, but it was never done, rather he had ruled for a long period in the name of enforcement of Islam in the country. After hanging Bhutto he had started spreading hatred against the democratic system.

There are armies that guard their nation's borders, these are those concerned with protecting their own position in society and there are those that defend a cause or an idea, but the Pakistan army does all these. ${ }^{4}$

In the meanwhile, before handing over the charge to the elected government he obtained extraordinary authority on $2^{\text {nd }}$ March 1985 through $8^{\text {th }}$ amendment in the constitution.

$8^{\text {th }}$ amendment of 1985 had entirely changed the balance of authorities between the President and the Prime Minister. Now the President was authorized to take any step on the plea that National Security is at risk and or in his opinion constitutional machinery failed to handle the affairs and no one could challenge his partial decision. When these amendments were being considered in the assembly, few analysts could assess their long term impact on the history of Pakistan. Since we people are basically optimists and despite having faced bitter experiences in the past, expect that now the discretions are used in right directions. 5

Later on, by exercising these powers he removed the assembly and Muhammad Khan Junejo was sacked.

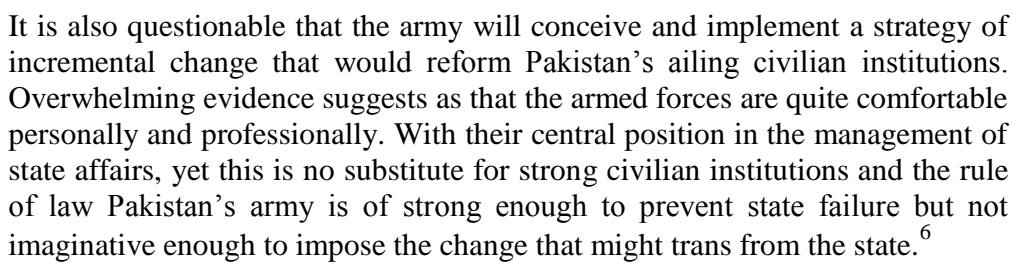

After this elections were held and the democracy was restored and Benazir Bhutto was took charge as first lady prime minister of the country. But on $6^{\text {th }}$ August 1990 availing the benefit of the $8^{\text {th }}$ amendment president Ishaque Khan had sacked the elected government of Benazir Bhutto. Besides this, several charges were levied against her and conflict started in courts. The Lahore High Court gave verdict in favour of this decision. Only the Peshawar High Court termed it an unlawful act.

Then Nawaz Sharif who was elected Prime Minister after Benazir Bhutto was also sacked by the President once again by using the powers and the assembly was removed. The Supreme Court termed this decision quite wrong and restored the government. But President Ishaque Khan appointed Moin-ud-Din Qureshi as Prime Minister and left the

\footnotetext{
${ }^{4}$ Cheema, Pervez Iqbal. The Armed Forced, (New York: Oxford University Press, 2002), p.135

${ }^{5}$ Safdar Mehmood. History and Politics of Pakistan, (Lahore: Publisher Jahngir Books, 1990), .302

${ }^{6}$ Stephen Philip Cohen. The Idea of Pakistan, (Karachi: Vanguard Books, 2005), p.274
} 
position after handing over the charge of acting President to Chairman Senate Waseem Sajjad. Prior to this such a big change never occurred in the history of Pakistan, except for Marshall Law. Again Benazir Bhutto was elected Prime Minister for the second time but President Sardar Farooq Ahmed Khan Leghari making fun of democracy removed her on $5^{\text {th }}$ November 1996 after leveling heinous charges of corruption on the government. This process remained continued.

One of the dark sides of this so called democracy was that the opposition focused its attention and ability to please of GHQ. During this period the President sacked all the governments under his special authority fixing them corrupt and fruitless. The governments formed during this period have limited authority. If these governments are not directly kept under the control of GHQ, atleast these were under their guidance. Recently on PTV, an ex-Federal Minister of Peoples Party disclosed that till date no Prime Minister ever allowed to visit Kahuta Atomic Plant. Form this revelation the state of affairs and conduct of civil governments can easily be assessed! ${ }^{7}$

The President Ghulam Ishaque Khan sacked the governments of Benazir Bhutto and Nawaz Sharif in 1990 and 1993 respectively. Use of presidential powers for sacking the elected governments was itself disappointed but more aggrieved were the circumstances which compelled to use these powers. ${ }^{8}$

After this Nawaz Sharif again got a chance to become in after elections but due to not having good relations with Army Chief General Pervez Musharraf he was removed from the government on 12 October 1999.

Pervez Musharraf came to power on $13^{\text {th }}$ October 1999 in dramatic circumstances which could almost have been scripted in Bollywood. Nawaz Sharif's attempt to sack him in a national television broadcast and hijack his plane en route from Colombo to Karachi enabled the Chief of Army Staff to pose as a reluctant Coup Maker in reality tensions had been growing between the army and the Pakistan Prime Minister. Since the kargil conflict in July in which Musharraf was a leading strategist. ${ }^{9}$

And General Pervez Musharraf took over the charge of the country.

Where civil institutions are not capable to prove their significance over the forces, the forces gain the upper hand over civil institutions. This is the root cause of this indisposition cure of which should be arranged. The Sooner we realized it, the better it is. 10

After a long period General Pervez Musharraf hat arranged elections Pakistan People's Party (PPP) not only took part in these elections but also was successful and in the history of Pakistan proved first civil government which had completed its tenure. Afterwards Nawaz Sharif got the chance to come in power which is still continued. But soon after

\footnotetext{
${ }^{7}$ Muhammad Asghar Khan. Noting Learnt from the History, (Islamabad: Dost Publication, 2012), p.243

${ }^{8}$ Ian Talbot, Pakistan - A Modern History, (Lahore: Takhleeqat, 2007), pp.429-430

${ }^{9}$ Ian Talbot. Pakistan a New History, (Karachi: Oxford University Press, 2012), p.169

${ }^{10}$ Stephen Philip Cohen. The Pakistan Army, (London: University of California Press, 1984), p.119
} 
completing four years, the Prime Minister Nawaz Sharif was declared incapable and Mr. Shahid Khaqan Abbasi was elected the new Prime Minister. Mr. Nawaz Sharif was declared unworthy by the court of law and not by a single person or a military institution.

\section{Methodology}

The current study has been made in order to take proper steps in the light of historical background to safe to the democracy from the harms faced after freedom during the last 70 years.

The democracy is such a process through which elections are held at regular intervals, democratic government is formed having the upper hand of the people, aim to establish a welfare state by finishing feudalism and control of military over livelihood. Since this subject has similarity and conformity to my thesis, therefore, this article has been arranged based on the qualitative method.

It is the need of the time that democratic institutions should be allowed to work freely, if we want to progress with the present world.

\section{Research Questions}

- Why the constitution remained un-durable and democratic institutions could not be established?

- Whether democratic governments and democratic system is unsuccessful in Pakistan?

\section{Literature Review}

Mr Babar Ayaz in his book What's Wrong With Pakistan, has given realistic arguments about the democratic governments in Pakistan. Keeping in view the historical background, he has highlighted various issues. In chapter 32 of $6^{\text {th }}$ part of the book, he reviewed democracy in very logical manner. He says, that root issues of a common man in Pakistan are, terrorism, religious extremism, sectarian hatred, racial killing, deteriorating peace and security and bad governess in government institutions. These issues did not arise due to democracy but were increased for not allowing the democracy to work. ${ }^{11}$

In the book Pakistan Ki Tareekh-o-Siasat, Mr Safder Mehmood has described that the political history, preparation of constitution, conduct of political parties and different ages of external policy have been discussed in detail. In $5^{\text {th }}$ chapter of the book the performance of various democratic experiences done during the period from 1947 to 1988 has been discussed. ${ }^{12}$

\footnotetext{
${ }^{11}$ Babar Ayaz, What's wrong with Pakistan (UK: Hay House, 2013).

${ }^{12}$ Safdar Mehmood, Pakistan Ki Tareekh-o-Siasat (History and Politics of Pakistan), (Lahore: Jahangir Books, 1990)
} 
In this chapter I have found ample matter about the behavior of political leadership public efforts, review of state of affairs created due to frequent discontinuation of election process and how army and bureaucracy could not allowed to flourish democracy in different eras of national history.

In the book of Asghar Khan Tareekh se Kuch Naheen Seekha (Nothing Lernt from the History) the author in his autobiography narrated the events up to the period of General Pervez Musharraf in a quite comprehensive manner. How armed forces started interference in politics, Ayub Khan's dictatorship, public agitation against him for restoration of democracy, tyrannic military action in former East Pakistan, not handing over the powers to Sheikh Mujeeb-ur-Rehman even after holding the elections, reign of Zulfiqar Ali Bhutto after the fall of East Pakistan and coming up of Zia-ul-Haq in power due to his stubbornness in not conducting fresh elections etc. have been discuss in detail. This book provided me great help in writing this article. ${ }^{13}$

In thirteen chapters of the book Pakistan In The Twentieth Century the author has reviewed the history of Pakistan. The whole book describes the establishment of Pakistan and its background, obstacles in the process of preparation of constitution, failure of traditional politics, and imposition of Marshall Law by the President Ayub Khan and the reasons of fall of East Pakistan. ${ }^{14}$

In Chapter $11^{\text {th }}$ provides comprehensive information about restoration of democracy and sacking of the government of Nawaz Sharif and Benazir Bhutto, reading of which made me able to write a neutral analysis.

- "Civil Aur Fauji Sazishen" (Civil and Military Conspiracies) - written by Rafique Dougar, printed in 1996.

He has written a research book on the history and politics of Pakistan which unfolds the Military conspiracies. In this book along with army generals he has discussed the political leadership and told that why the democratic institutions and democracy could not become prosper. In $9^{\text {th }}$ Chapter of the book he has discussed that instead of handing over the power to the winners of elections, East Pakistan was separated after having done army action against them. Apart from this in $21^{\text {st }}$ Chapter he has discussed second elections held in Bhutto's period which were conducted by using the unfair means and how Bhutto had invited General Zia-ul-Haq to take charge of the country by imposing Marshall Law just for not holding fresh elections. The book also reveals that all the leadership from Liaquat Ali Khan to Bhutto had given importance to the cooperation of the army instead of people. $4^{\text {th }}$ Chapter of the book unfolds first conspiracy of the army in a quite comprehensive way. By reading it, one's information is increased further and realities unearthed.

\footnotetext{
${ }^{13}$ Muhammad Asghar Khan, Tareekh Se Kuch Naheen Seekha" (Noting Learnt from the History) (Karachi: Liberty Books, 2012).

${ }^{14}$ Lawrence Zyring, Pakistan In The Twentieth Century: A Political History, (Oxford University Press, 2006).
} 
- “Pakistan - A Modern History" - written by Ian Talbot, Published in 2007.

In $10^{\text {th }}$ and $11^{\text {th }}$ Chapter of Part -4 of the book, beside restoration of democracy and democratic crisis, issues like, corruption, abnormal condition of Karachi, political issues and confrontation, sectarianism, non-completion of tenure of democratic government despite holding repeated elections, and non-taking any notice of the deteriorating situation etc. etc. have been discussed. Besides, issues like, delay in preparation of constitution, deferring of elections, the study of this book reveals full review on more than half of the portion of the political history of Pakistan.

The second book of the author, "Pakistan a new history" which was published in 2012 provides me a detailed review since establishment of Pakistan to Zardari's reign. The $6^{\text {th }}$ Chapter of the book presents the political situation prevailing since 1988 to 1998. In Chapter 2, the writer has examined the reasons of failure of democratic system since 1947 to 1958 . How Governor General Ghulam Muhammad had removed the constituent assembly and did not allow the democracy to go ahead. From this book I got a gist of the whole history of Pakistan.

\title{
Discussion
}

Soon after came into existence of Pakistan beside amendments in constitution such laws were made due to thath the democratic process could not bring its root up. In the reign of Ayub Khan laws like, "Public Officers Disqualification Order" (PODO) and "Elective Bodies Disqualification Order" (EBDO) were enforced in 1959.

In terms of that officers and politicians will found guilty in any case not be able to take part in practical politics. This restriction was imposed for a minimum period of 6 years to the maximum period of 15 years. However, appeal was to be filed against it in the tribunal. Through enforcement of these laws the politicians were seemed to be forcedly retired.

\begin{abstract}
Sterner measures were used against the politicians. The Proda prescribed fifteen years exclusion from public office for those found guilty of corruption. The Elective Bodies Disqualification Order (EBDO) authorized special tribunals to try former politicians for misconduct an infraction not clearly defined. Prosecution could be avoided if the accused agreed not to be a candidate for any elective body for a period of seven years. About 7,000 individuals were "EBDO"ed. Some people including Suhrawardy, who were arrested, fought prosecution.
\end{abstract}

The Press and Publication Ordinance was amended in 1960 to specially broad publications could be commandeered or shut down trade organizations, unions, and student groups were closely monitored and cautioned to not be a part of political activity, and imams at mosques were warned against including political matters in sermons. ${ }^{15}$

"In order to terminate the democracy on constitutional grounds $8^{\text {th }}$ amendment was made and due to nullification of democracy room for abolish the leadership continued to aggrandize. From this amendment that was approved in 1985

${ }^{15}$ World Infopaedia Pakistan, Part-1, (New Delhi: Pragun Publication, 2007) pp.107-108 
various additional discretions were vested to the President. By exercising these powers he was allowed to assassinate the assembly. Through the amendment made in Article 58, President may remove the Prime Minister and his cabinet that was used by Zia-ul-Haq against Junejo. After this, it was used thrice in the decade of 1990.

However, this discretion was taken back from the president. In 1997 through $13^{\text {th }}$ amendment in the constitution. Then these authorities were again partially vested to the President but with the condition to obtain approval from Supreme Court before applying the same. ${ }^{16}$

Due to non-existence of democratic system the state institutions could not have sufficient time to balance their affairs. Struggle for obtainment of excess powers by the three significant institutions of the state i.e. Administration, Judiciary and Parliament did not allow the system to run.

In the period of Musharraf two political leaders abroad signed a pact in the name of "Democratic Alliance" in order to bring up the democracy. In accordance with this charter, principles for "Legal Framework Order" and mutual course of elections under $7^{\text {th }}$ amendment of the constitution were drawn up.

Two exiled political leaders, Nawaz Sharif and Benazir Bhutto signed a pact, "Charter of Democracy" in London in which they agreed upon to end the interruption of forces in polities, to make the political culture prosperous, nomination of judges of the courts, conducting of transparent elections and formation of bylaws to honour peoples mandate. The "Democratic Alliance" received a warm welcome by the advocates and political circles, as well as by the press. However, supporters of Pervez Musharraf had criticized it to safeguard their own interests. ${ }^{17}$

In the reign of Peoples Party National Assembly passed $18^{\text {th }}$ amendment in the constitution on $8^{\text {th }}$ April 2010 according to which all the executive discretions vested to the President were given to the parliament. As Prime Minister is the head of the parliament so in others words the entire authority was given to him.

When allied government under the leadership of Pakistan People's Party came in power, the Pakistan Muslim League (N) of Nawaz Sharif pressurized the government to act upon "Democratic Alliance". They argued to immediately cancel the $17^{\text {th }}$ amendment. But the allied government formed under Pakistan People's Party leadership wisely liked it to the issues of self-provincial government and the requisition of NWFP. ${ }^{18}$

Without any doubt, army in Pakistan always remained a forceful authority, who never admitted sovereignty of civilian governments. But now it is a part of the past and present act they have open heartedly confined them to the borders in order to make the

${ }^{16}$ www.wikipedia.com (accessed, 26.08.2017)

${ }^{17}$ Qayyum Nizami. Generals and Politicians in the Court of History, (Lahore: Jahngir Book Depot, 2006), p. 210

${ }_{18}^{18}$ Babar Ayaz, Whats Wrong with Pakistan?, (Lahore: Fiction House, 2014),p.123 
democracy prosperous, due to which Zardari's government could complete its tenure and Nawaz Sharif's government is on the way to complete its period.

Mr. Nawaz was striving for to complete his tenure but in the meantime "Panama Revelation" caused uproar in the international politics. Documentary proof through Vicki leaks came in picture throughout the world. One of the German newspapers published this as "Panama Papers". In these papers names of all the three children of Nawaz Sharif were also included. Several Prime Ministers and dignitaries of the world have left their positions in such cases. But here was the Prime Minister of Pakistan himself.

How off shore companies were established and properties purchased. How such a big amount was transferred from the country. Sharif family could not provide solid evidence in their support. Such a huge amount could only be transferred through State Bank of Pakistan but in this case it was not done. The amount was not remitted by using the proper channel but by adopting some unfair means. Resultantly, Sharif family was trapped in their corruption. Morally Nawaz Sharif should have been resigned himself but he did not. The chairman of Pakistan Tehreek-e-Insasaf (PTI) Mr. Imran Khan had paid a leading role in this case. Apart from him Sheikh Rashid Ahmed of Awami Muslim League had also paid an active role to follow the case. The Sharif government was questioned in a democratic way as well as legal action initiated to investigate the source of this money. The case had lingered on for a year and after undergoing through different stages and stopovers viz issuance of letter of Qatari Prince and formation of JIT etc. was finally decided by the Supreme Court on $28^{\text {th }}$ July 2017. As a result of it longest act of sitting in protest also accrued in the history of the country. The 5 Judges of Supreme Court declared Nawaz Sharif incapable for not disclosing the assets and NAB was ordered to lodge five references against Sharif family.

The aim of writing this article is not to down ones morale, Pakistani forces is an institution, having full feelings of patriotism. On the basis of wrong doings of few generals, the whole honourable institution cannot be blamed.

There is a great part have been participated by our politicians as well in the failure of democracy, who in covetousness of power and to obtain their own personal benefits caused a great loss to the country and the nation. But it does not mean that democratic system is wretched just due to few corrupt politicians.

But the main object of writing this article is to strengthen the democracy so that we may go ahead together with the present developed world. There should be no obstruction and hardship in the way of democracy.

One of the realities in Pakistan is co-operation of feudatory with army, who apparently claim themselves democratic people, but in fact they have strong relations with the army and did not feel it indecent. In their view entire requirements of democracy are fulfilled just by getting access to the power. Therefore, in Pakistan behind sacking of democratic governments forces, bureaucracy, politicians and our so called religious leaders and religious parties, are equally play an important role. The democracy cannot be successful until and unless it is free from corruption and transparent elections are held and the power 
delegated to the successful ones. In fact, a welfare state can be established through the rule of people.

\section{Conclusion}

It has become necessary to make the democracy prosperous and to allow the political institutions to work freely. The first general election were held in 1970 i.e. 23 years after getting freedom. Before this, the people were kept away from the political process. It does not mean that they had no political consciousness. If so, they might have not taken part in the elections of 1970 with full eagerness. But our forces and politicians missed the opportunity and the country was divided into two parts. After it although the coming period was not so good for the democratic governments and institutions, but this hypothesis is absolutely baseless that the democracy has been failed in Pakistan, whereas in fact the democratic institutions were never allowed to work. This was only due to the democracy which provide courage to the armed forces to fight against the terrorists and in the mission of Zarb-e-Azab the civilian government and all the political parties stood with forces to strengthen their hands. Due to coalition of political parties and the democratic process the Karachi Operation is successfully being continued. With the concurrence of political parties, sectarian division is continuously going to the down. Due to continuation of this democratic system healthy decisions are being given by the courts. Not only the Prime Minister was terminated by the courts, but also they ordered the government to write letter to Swiss government and to continue hearing of the suit filed against the President Zardari, for corruption. This democratic system had got approved $18^{\text {th }}$ the amendment in the constitution. For the first time in the history of Pakistan suits against various army generals were filed. The provinces got discretions after 66 years of independence. "The Notional Finance Award" was approved.

The decision of Supreme Court was given on $28^{\text {th }}$ July 2017. As a result of it longest act of sitting in protest also accrued in the history of the country. The 5 Judges of Supreme Court declared Nawaz Sharif incapable for not disclosing the assets and National Accountability Bureau (NAB) was ordered to lodge five references against Sharif family. The hearing of the reference lodged against Sharif family by the NAB will be started in the coming days. The democratic system is on its way and the nation is satisfied with this decision. The interest of the people in the country politics and awareness of their nights is increasing which is the main mission of democracy. This shows that the democracy did not fail in the country, but contrary to it, the democratic process is going ahead towards the destination though slowly.

It seems, the democratic process, rather slow or disappointing at some time, should be allowed to continue because democracy is such a process, through which chance is unanimously given to the elected members to rule. If they prove worthless, they can easily be removed as per constitution, because "the worst democracy is far better than the best dictatorship!" 